\title{
Detection of virulence-associated and regulatory
protein genes in association with phage typing of
human Vibrio cholerae from several geographical
regions of the world \\ Correspondence \\ B. L. Sarkar \\ bl_sarkar@hotmail.com \\ Received 3 December 2008 \\ Accepted 26 May 2009

\author{
Tushar Suvra Bhowmick, ${ }^{1}$ Mayukh Das, ${ }^{1}$ Werner Ruppitsch, ${ }^{2}$ \\ Anna Stoeger, ${ }^{2}$ Ariane Tatjana Pietzka, ${ }^{2}$ Franz Allerberger, ${ }^{2}$ \\ D. P. Rodrigues ${ }^{3}$ and B. L. Sarkar ${ }^{1}$
}

\author{
${ }^{1}$ Division of Bacteriology, National Institute of Cholera and Enteric Diseases, Kolkata, India \\ ${ }^{2}$ Austrian Agency for Health and Food Safety (AGES), Vienna, Austria \\ ${ }^{3}$ Instituto Oswaldo Cruz, Rio de Janeiro, Brazil
}

\section{INTRODUCTION}

Acute diarrhoea is a common cause of death in developing countries and is the second most common cause of infant deaths worldwide. Among the many causal organisms, only Vibrio cholerae has caused repeated pandemics (Wachsmuth et al., 1994), dating from the pandemics of the 19th century to recent major epidemics in South America and Africa. V. cholerae is subdivided into more than 208 somatic O-antigen serogroups, but only two serogroups, $\mathrm{O} 1$ and $\mathrm{O} 139$, are recognized as pathogenic for man and as responsible for epidemic and pandemic cholera (Kaper et al., 1995). In contrast, non-O1/non-O139 serogroups of $V$. cholerae may cause sporadic diarrhoeal episodes ranging from mild to severe morbidity (Kaper et al., 1995; Mukhopadhyay et al., 1995; Ramamurthy et al., 1993).

The pathogenic variants of $V$. cholerae express genes encoding virulence-associated factors; in order to cause diarrhoea, strains require genes for the cholera toxin, the colonization factor TCP (toxin-coregulated pilus) and the central regulatory protein ToxR (Hall et al., 1994;

Abbreviation: NICED, National Institute of Cholera and Enteric Diseases.
Herrington et al., 1988; Levine et al., 1988; Miller et al., 1989). It has become evident from earlier reports that a new epidemic $V$. cholerae clone could emerge by acquisition and combination of crucial virulence genes from the environmental pool through horizontal gene transfer (Faruque et al., 2004). As a result, genotypic surveillance of pathogenic and virulence-associated genes in strains isolated from various localities nationally and internationally is monitored in order to identify the origin and circulation of strains with epidemic potential.

Among several typing methods, phage typing is one of the most important and useful methods for the identification and differentiation of $V$. cholerae strains. The two phage typing schemes for $V$. cholerae $\mathrm{O} 1$ and $\mathrm{O} 139$ were developed in, and are in routine use at, the National Institute of Cholera and Enteric Diseases (NICED) (Chakrabarti et al., 1997; Chattopadhyay et al., 1993). As a World Health Organization collaborating centre for diarrhoeal diseases research and training, NICED is a national reference laboratory and receives 700-1000 strains of $V$. cholerae per year from different parts of India and abroad for biotyping, serotyping and phage typing. We report here an analysis of the virulence gene cassettes of $V$. 
Table 1. Distribution of biotype, serotype and phage type of $V$. cholerae isolates from different parts of the world

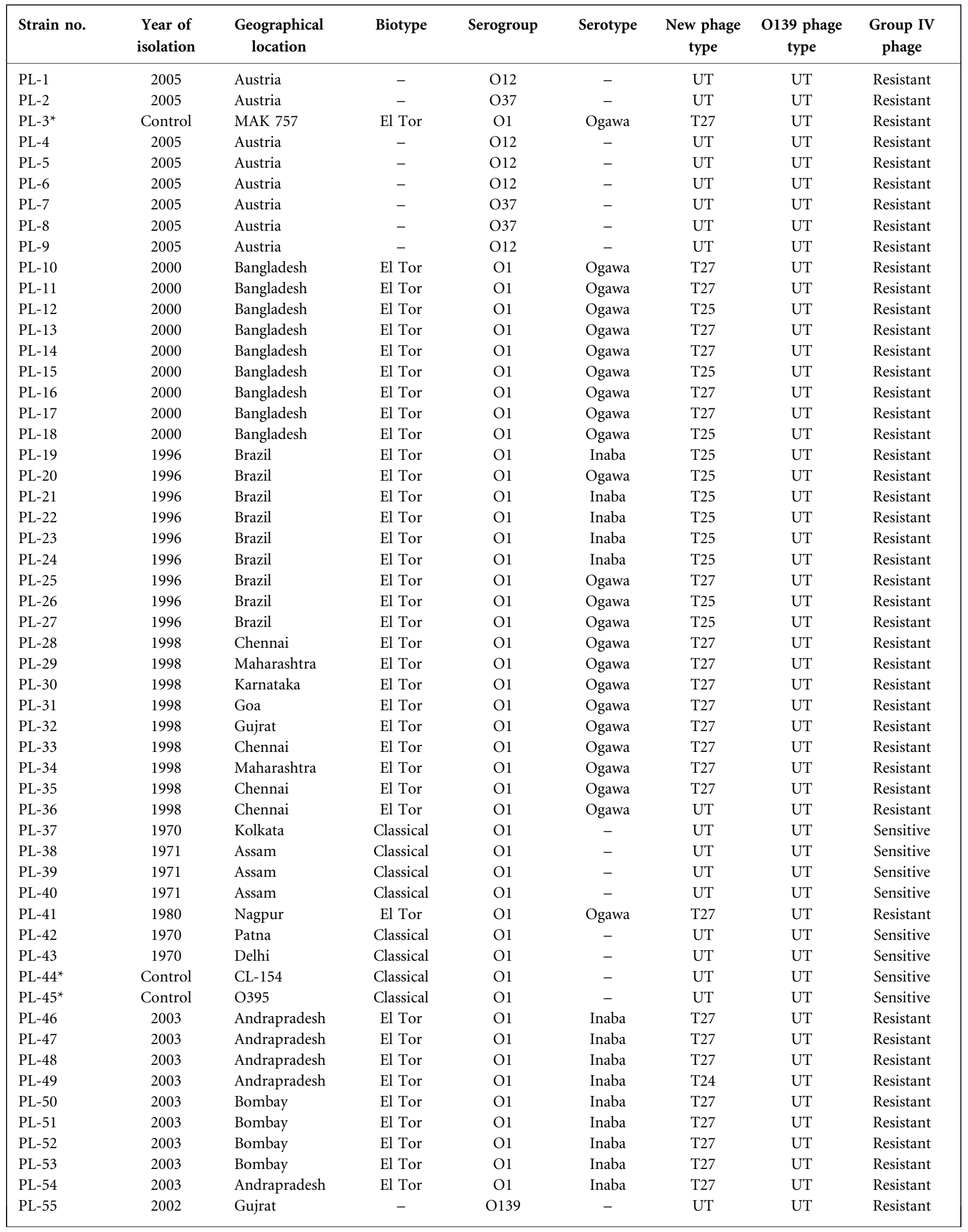


Table 1. cont.

\begin{tabular}{|c|c|c|c|c|c|c|c|c|}
\hline Strain no. & $\begin{array}{c}\text { Year of } \\
\text { isolation }\end{array}$ & $\begin{array}{c}\text { Geographical } \\
\text { location }\end{array}$ & Biotype & Serogroup & Serotype & $\begin{array}{c}\text { New phage } \\
\text { type }\end{array}$ & $\begin{array}{c}\text { O139 phage } \\
\text { type }\end{array}$ & $\begin{array}{c}\text { Group IV } \\
\text { phage }\end{array}$ \\
\hline PL-56 & 2002 & Gujrat & - & O139 & - & UT & UT & Resistant \\
\hline PL-57 & 2002 & Gujrat & - & O139 & - & UT & UT & Resistant \\
\hline PL-58 & 2004 & Gujrat & - & O139 & - & UT & UT & Resistant \\
\hline PL-59 & 2004 & Gujrat & - & O139 & - & UT & UT & Resistant \\
\hline PL-60 & 2004 & Chennai & - & O139 & - & UT & UT & Resistant \\
\hline PL-61 & 2002 & Chennai & - & O139 & - & UT & UT & Resistant \\
\hline PL-62 & 2002 & Chennai & - & O139 & - & UT & UT & Resistant \\
\hline PL-63 & 2004 & Chennai & - & O139 & - & UT & UT & Resistant \\
\hline PL-64 & 2001 & Goa & El Tor & $\mathrm{O} 1$ & Ogawa & UT & UT & Resistant \\
\hline PL-65 & 2001 & Delhi & El Tor & $\mathrm{O} 1$ & Ogawa & UT & UT & Resistant \\
\hline PL-66 & 2001 & Bikaner & El Tor & $\mathrm{O} 1$ & Ogawa & UT & UT & Resistant \\
\hline PL-67 & 2001 & Delhi & El Tor & $\mathrm{O} 1$ & Ogawa & UT & UT & Resistant \\
\hline PL-68 & 2001 & Goa & El Tor & $\mathrm{O} 1$ & Ogawa & UT & UT & Resistant \\
\hline PL-69 & 2001 & Bikaner & El Tor & O1 & Ogawa & UT & UT & Resistant \\
\hline PL-70 & 2001 & Baroda & - & $\begin{array}{c}\text { Non-O1/non- } \\
\text { O139 }\end{array}$ & - & UT & UT & Resistant \\
\hline PL-71 & 2001 & Baroda & - & $\begin{array}{c}\text { Non-O1/non- } \\
\text { O139 }\end{array}$ & - & UT & UT & Resistant \\
\hline PL-72 & 2001 & Baroda & El Tor & $\mathrm{O} 1$ & Ogawa & $\mathrm{T} 27$ & UT & Resistant \\
\hline PL-73 & 2006 & Delhi & - & O139 & - & UT & $\mathrm{T} 1$ & Resistant \\
\hline PL-74 & 2006 & Delhi & - & O139 & - & UT & $\mathrm{T} 1$ & Resistant \\
\hline PL-75 & 2006 & Delhi & - & O139 & - & UT & $\mathrm{T} 1$ & Resistant \\
\hline PL-76 & 2006 & Delhi & - & O139 & - & UT & $\mathrm{T} 1$ & Resistant \\
\hline PL-77 & 2006 & Delhi & - & O139 & - & UT & $\mathrm{T} 1$ & Resistant \\
\hline PL-78 & 2006 & Delhi & - & O139 & - & UT & $\mathrm{T} 1$ & Resistant \\
\hline PL-79 & 2006 & Delhi & - & O139 & - & UT & $\mathrm{T} 1$ & Resistant \\
\hline PL-80 & 2006 & Delhi & - & O139 & - & UT & $\mathrm{T} 1$ & Resistant \\
\hline PL- $81^{*}$ & Control & NPR-4 & - & O139 & - & UT & $\mathrm{T} 1$ & Resistant \\
\hline PL-82 & 2007 & Kolkata & El Tor & $\mathrm{O} 1$ & Ogawa & $\mathrm{T} 25$ & UT & Resistant \\
\hline PL-83 & 2007 & Kolkata & El Tor & $\mathrm{O} 1$ & Ogawa & T16 & UT & Resistant \\
\hline PL-84 & 2007 & Kolkata & El Tor & $\mathrm{O} 1$ & Ogawa & $\mathrm{T} 24$ & UT & Resistant \\
\hline PL-85 & 2007 & Kolkata & El Tor & $\mathrm{O} 1$ & Ogawa & $\mathrm{T} 25$ & UT & Resistant \\
\hline PL-86 & 2007 & Kolkata & El Tor & $\mathrm{O} 1$ & Ogawa & $\mathrm{T} 25$ & UT & Resistant \\
\hline PL-87 & 2007 & Kolkata & El Tor & $\mathrm{O} 1$ & Ogawa & $\mathrm{T} 25$ & UT & Resistant \\
\hline PL-88 & 2007 & Kolkata & El Tor & $\mathrm{O} 1$ & Ogawa & $\mathrm{T} 24$ & UT & Resistant \\
\hline PL-89 & 2007 & Kolkata & El Tor & $\mathrm{O} 1$ & Ogawa & $\mathrm{T} 27$ & UT & Resistant \\
\hline PL-90 & 2007 & Kolkata & El Tor & $\mathrm{O} 1$ & Ogawa & $\mathrm{T} 27$ & UT & Resistant \\
\hline
\end{tabular}

${ }^{\star}$ These strains were used as controls in this study.

cholerae received from geographical regions of India and internationally over the last three decades and their correlation with phenotypic typing.

\section{METHODS}

Strains. Eighty-six $V$. cholerae strains, comprising $53 \mathrm{O} 1$ biotype $\mathrm{El}$ Tor, six O1 biotype classical, 17 serogroup O139 and 10 non-O1/nonO139, isolated from diarrhoeal patients, were selected from strains submitted to NICED from different geographical regions of India and abroad from 1970 to 2007 for species confirmation, biotyping, serotyping and phage typing (Table 1$)$. V. cholerae O1 biotype El Tor strain MAK 757 (ATCC 51352) (PL-3), two V. cholerae O1 biotype classical strains, CL-154 (PL-44) and O395 (PL-45), and V. cholerae
O139 strain NPR-4 (PL-81) were used as control strains. Strains were maintained in nutrient agar (HiMedia) stabs and stored in the dark in the repository of the Vibrio Phage Reference Laboratory, NICED.

Bacteriology. Strains were plated on thiosulfate-citrate-bile saltsucrose agar (Eiken) and incubated at $37^{\circ} \mathrm{C}$ for $16-18 \mathrm{~h}$. V. cholerae was identified and confirmed by standard techniques (WHO, 1993). Strains were serotyped using polyvalent $\mathrm{O} 1$ and monospecific Inaba and Ogawa antisera, and monoclonal antibody O139 (Difco) and non-O1/non-O139 serogroup-specific antiserum (Thermo Fisher Scientific, Remel Products).

Phage typing. Phage typing was performed by the standard methodology of our laboratory (Sarkar et al., 1994). After incubation, each reaction was recorded as positive if the number of plaques was 
Table 2. Sequences of primers used for the detection of virulence and regulatory genes of $V$. cholerae isolates

\begin{tabular}{|c|c|c|c|c|}
\hline Gene & Primer sequence $\left(5^{\prime} \rightarrow 3^{\prime}\right)$ & $\begin{array}{l}\text { Amplicon } \\
\text { (bp) }\end{array}$ & $\begin{array}{l}\text { Annealing temp. } \\
\qquad\left({ }^{\circ} \mathrm{C}\right)\end{array}$ & Reference \\
\hline $\operatorname{ctx} A$ & CGGGCAGATTCTAGACCTCCTG & 564 & 60 & Singh et al. (2002) \\
\hline \multirow[t]{2}{*}{$z o t$} & TCGCTTAACGATGGCGCGTTTT & 947 & 60 & Singh et al. (2002) \\
\hline & AACCCCGTTTCACTTCTACCCA & & & \\
\hline sxt & TCGGGTATCGCCCAAGGGCA & 920 & 60 & Bhanumathi et al. (2003) \\
\hline \multirow[t]{2}{*}{ ace } & TAAGGATGTGCTTATGATGGACACCC & 289 & 55 & Singh et al. (2002) \\
\hline & CGTGATGAATAAAGATACTCATAGG & & & \\
\hline \multirow[t]{2}{*}{ ompU } & ACGCTGACGGAATCAACCAAAG & 869 & 60 & Singh et al. (2002) \\
\hline & GCGGAAGTTTGGCTTGAAGTAG & & & \\
\hline \multirow[t]{2}{*}{$V c-O 1$} & CAACAGAATAGACTCAAGAA & 647 & 55 & Binsztein et al. (2004) \\
\hline & TATCTTCTGATACTTTTCTAC & & & \\
\hline \multirow[t]{2}{*}{ tcpA El Tor } & CACGATAAGAAAACCGGTCAAGAG & 453 & 60 & Singh et al. (2002) \\
\hline & CGAAAGCACCTTCTTTCACACGTTG & & & \\
\hline \multirow[t]{2}{*}{ toxR } & CCTTCGATCCCCTAAGCAATAC & 779 & 60 & Singh et al. (2002) \\
\hline & AGGGTTAGCAACGATGCGTAAG & & & \\
\hline \multirow[t]{2}{*}{ hlyA classical } & GGCAAACAGCGAAACAAATACC & 738 & 60 & Singh et al. (2001) \\
\hline & CTCAGCGGGCTAATACGGTTTA & & & \\
\hline \multirow[t]{2}{*}{ hlyA El Tor } & GAGCCGGCATTCATCTGAAT & 481 & 60 & Singh et al. (2001) \\
\hline & CTCAGCGGGCTAATACGGTTTA & & & \\
\hline \multirow[t]{2}{*}{$r t x A$} & GCGATTCTCAAAGAGATG & 1366 & 55 & O'Shea et al. (2004), Lin et al. (1999) \\
\hline & CACTCATTCCGATAACCAC & & & \\
\hline $\operatorname{tcpI}$ & TAGCCTTAGTTCTCAGCAGGCA & 862 & 60 & Singh et al. (2001) \\
\hline \multirow[t]{2}{*}{$A C F-s s r A$} & KAR442: TTTCTCTCTAGGTTTGGAGG & 908 & 55 & Rajanna et al. (2003) \\
\hline & KAR86: GCAGCAAGCCTCCACTCCG & & & \\
\hline \multirow[t]{2}{*}{$A C F$ (int gene) } & KAR22: GATAAAGAGATCAAAGCC & 1237 & 55 & Karaolis et al. (1998) \\
\hline & KAR23: ATCTGCTTCCATGTGGG & & & \\
\hline \multirow[t]{2}{*}{ aldA } & KAR3: AATAGCGAAACTTCGAC & 1485 & 55 & Karaolis et al. (1998) \\
\hline & KAR7: CCTCTAGGTCTATTTTA & & & \\
\hline \multirow[t]{2}{*}{ ssrA left } & KAR94: TATGATACTGAAAACACCTC & 1455 & 50 & Karaolis et al. (1998) \\
\hline & KAR95: GATGCTAACAGCAGAGCATA & & & \\
\hline
\end{tabular}

five or more. The 'classical' phage ( $\phi 149$ of Basu and Mukerjee classical group IV phage) was used to detect and confirm strains belonging to biotype classical. For O1 biotype classical strains, the reference strains CL-154 and O395 were used as controls, and for O1 and O139 strains, MAK 757 and NPR-4 were used, respectively, for confirmation of phage type.

Virulence-associated and regulatory protein genes. Strains were examined for the presence of the virulence-associated genes $c t x A$, zot, ace, RS1, hlyA, rtxA, ompU, sxt and $t c p A$, the regulatory genes for TCP expression (tcpI), and the central regulatory protein $(t o x R)$ and its two regulatory genes (aldA and tagA) (Chow et al., 2001; Huhulescu et al., 2007; Singh et al., 2001). Integration of the $V$. cholerae pathogenicity island into the chromosome of the strains was also investigated. Chromosomal DNA was extracted from each of the strains using a GenElute Bacterial DNA kit (Sigma-Aldrich). DNA was eluted with $50 \mu$ l elution buffer and used as template for PCR. The primers used and the expected amplicon sizes are listed in Table 2. PCR was performed with a PTC 200 Peltier thermal cycler (MJ Research). RedTaq Ready Mix ( $2 \times$; Sigma) was added to each sample in a $200 \mu \mathrm{l}$ PCR tube containing a reaction mixture volume of $25 \mu \mathrm{l}$ containing $1 \mu \mathrm{l}$ each forward and reverse primer $\left(10 \mathrm{pmol}^{-1} \mathrm{l}^{-1}\right)$ and $1 \mu \mathrm{l}$ DNA template. The PCR programme was initial denaturation $95{ }^{\circ} \mathrm{C}$ for $5 \mathrm{~min}$, followed by 35 cycles of $95{ }^{\circ} \mathrm{C}$ for $15 \mathrm{~s}$, the annealing temperature for respective primers (Table 2) for $35 \mathrm{~s}$ and $72{ }^{\circ} \mathrm{C}$ for $1.5 \mathrm{~min}$, followed by maintenance at $4{ }^{\circ} \mathrm{C}$. Reference strains MAK 
Table 3. Co-occurrence of virulence traits of $V$. cholerae isolates

\begin{tabular}{|c|c|c|c|c|}
\hline \multirow[t]{2}{*}{ Gene } & \multicolumn{4}{|c|}{ No. of strains of serogroup (biotype) containing each gene: } \\
\hline & O1 (classical) & O1 (El Tor) & 0139 & Non-O1/non-O139 \\
\hline$t c p I$ & 6 & 53 & 17 & 10 \\
\hline $\operatorname{tcp} A$ (classical) & 6 & 38 & 12 & 5 \\
\hline $\operatorname{tcp} A$ (El Tor) & 6 & 52 & 17 & 10 \\
\hline $\operatorname{ssr} A R$ & 6 & 53 & 17 & 7 \\
\hline$A C F-s s r A$ & 6 & 44 & 15 & 0 \\
\hline$A C F($ int $)$ & 6 & 52 & 17 & 1 \\
\hline ssrAL & 1 & 43 & 12 & 0 \\
\hline$V c-O 1$ & 6 & 50 & 3 & 7 \\
\hline$V_{c-O}-0139$ & 0 & 0 & 17 & 0 \\
\hline $\operatorname{ctx} A$ & 6 & 53 & 17 & 10 \\
\hline$z o t$ & 6 & 53 & 17 & 10 \\
\hline ace & 6 & 53 & 17 & 10 \\
\hline RS1 & 6 & 51 & 17 & 10 \\
\hline toxR & 6 & 53 & 17 & 10 \\
\hline $\operatorname{tag} A$ & 4 & 39 & 13 & 0 \\
\hline ald $A$ & 0 & 0 & 0 & 0 \\
\hline hlyA (classical) & 6 & 53 & 17 & 10 \\
\hline hlyA (El Tor) & 6 & 53 & 17 & 10 \\
\hline ompU & 6 & 53 & 17 & 10 \\
\hline$r t x A$ & 6 & 53 & 17 & 10 \\
\hline$s x t$ & 6 & 52 & 17 & 10 \\
\hline Total no. of strains & 6 & 53 & 17 & 10 \\
\hline
\end{tabular}
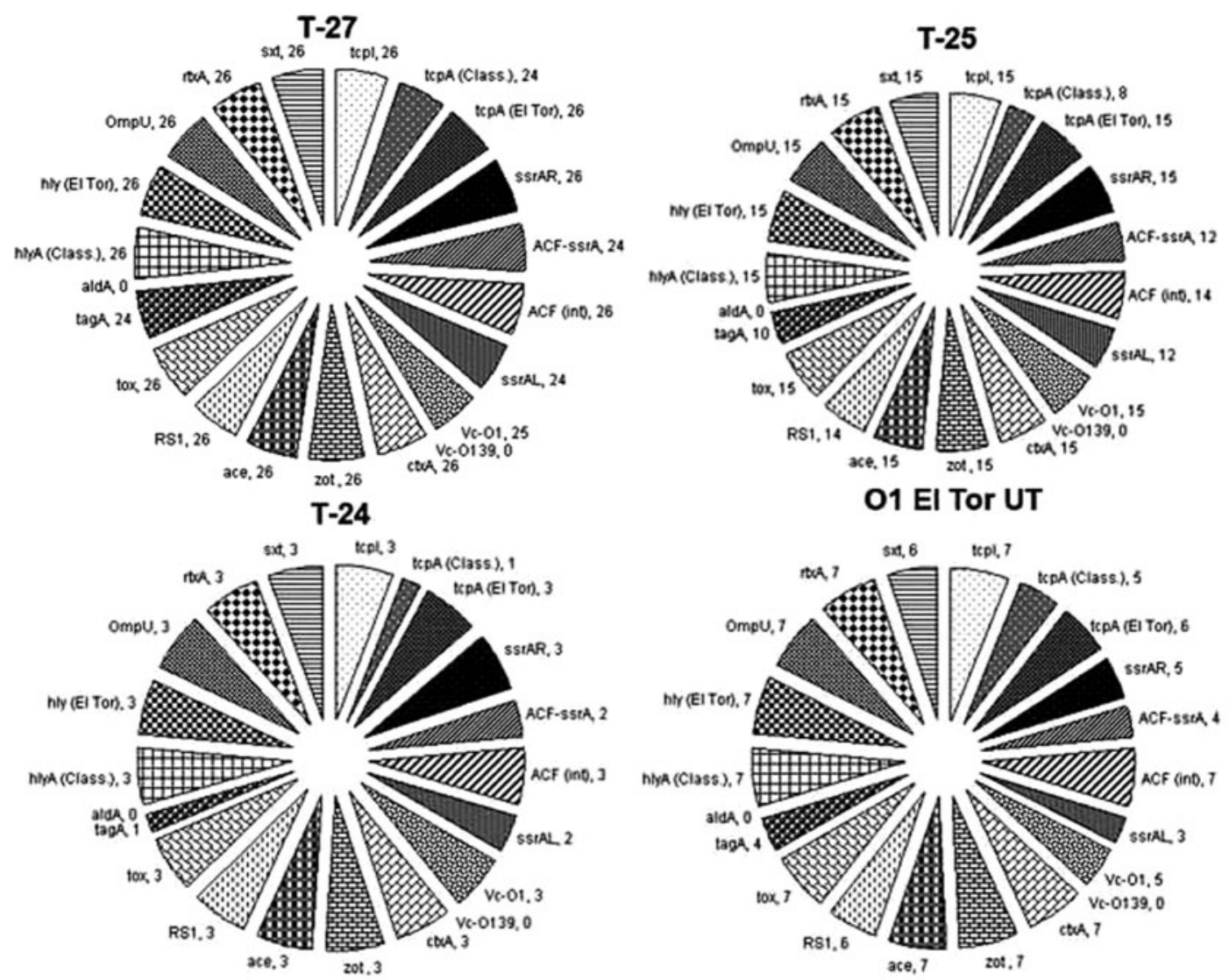

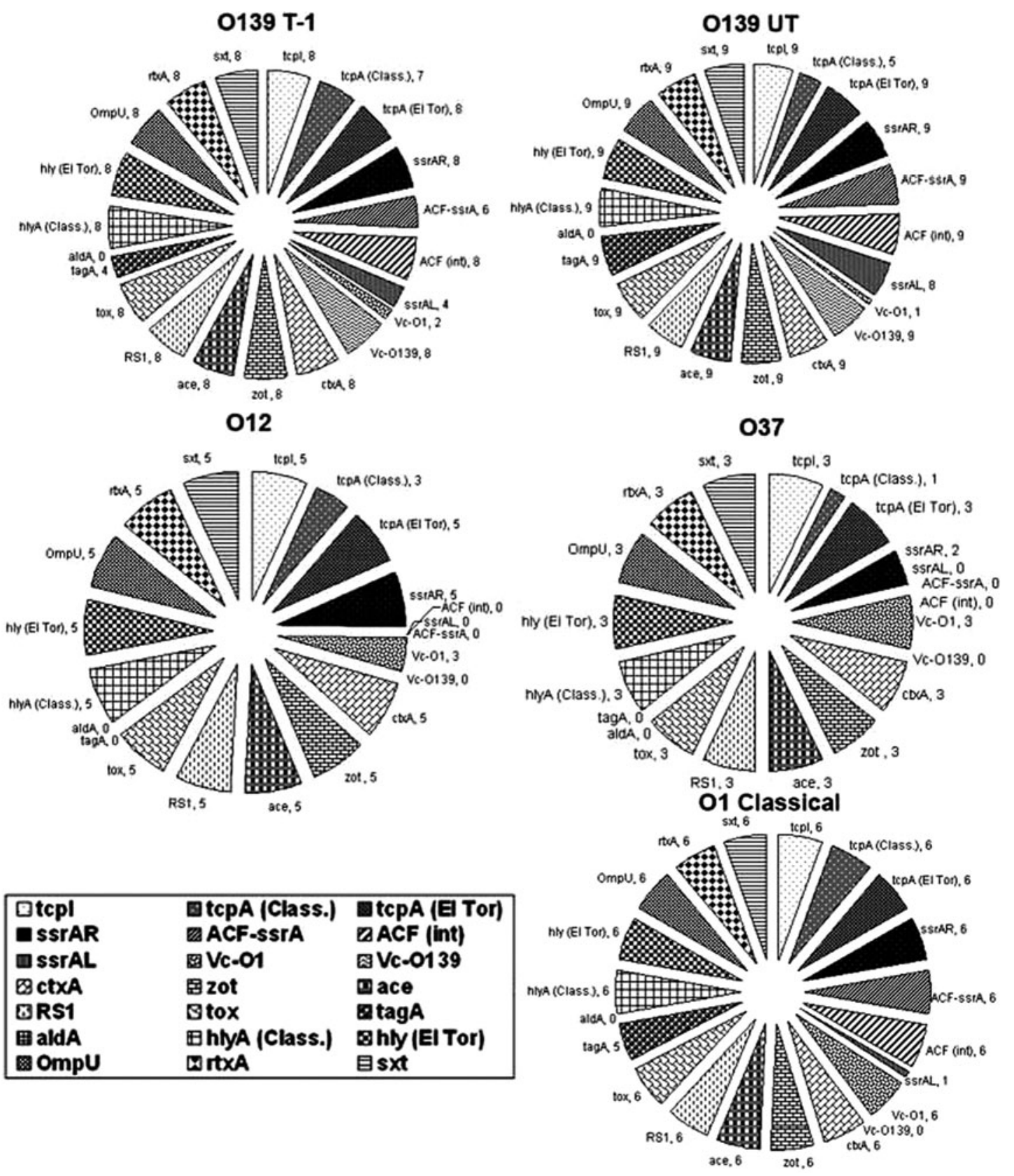

\begin{tabular}{|c|c|c|}
\hline 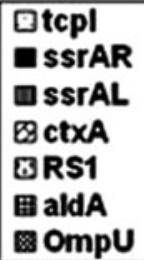 & 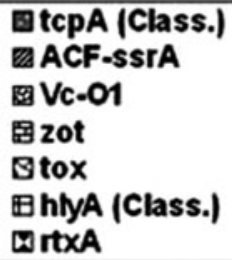 & 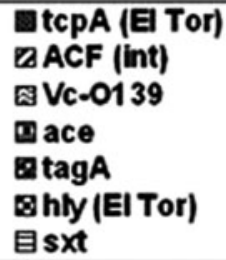 \\
\hline
\end{tabular}

Fig. 1. Virulence-associated and regulatory protein gene profiles within single phage types of $V$. cholerae.

757, NPR-4, CL-154 and O395 were used as positive controls. Amplified products were separated on a $1 \%$ agarose gel in $1 \times$ TAE, stained with ethidium bromide $\left(1.0 \mu \mathrm{g} \mathrm{ml}^{-1}\right)$ and visualized with a gel documentation system (Bio-Rad).

\section{RESULTS AND DISCUSSION}

The virulence and regulatory gene profiles of the $V$. cholerae strains are shown in Table 3. All $53 \mathrm{~V}$. cholerae O1 biotype El Tor strains were positive for CTX genes ( $\operatorname{ctxA}$, $z o t$ and ace), virulence genes (hlyA, ompU and $r t x A$ ), regulatory genes for TCP expression $(t c p I)$ and the central regulatory protein gene $($ toxR $)$. However, the regulatory genes toxR and tagA were also detected together in $38 \mathrm{El}$ Tor strains and none harboured aldA (Table 3). ToxR is a transmembrane transcriptional activator that is part of a complex virulence gene regulon that regulates cholera toxin and TCP synthesis and expression of the outermembrane protein OmpU (DiRita et al., 1991; Huhulescu et al., 2007).

All strains, irrespective of biotype, serotype, serogroup or phage type, were positive for $t c p A, c t x A, z o t$, ace, toxR, hly $A$, 
ompU and rtxA by PCR, indicating that the genes comprising the virulence gene cassette and the genes encoding surface organelles required for intestinal adherence and colonization were intact. Thirty-eight El Tor strains were characterized by the presence of both $\operatorname{tcp} A$ classical and tcpA El Tor genes. Similar results were also obtained for the V. cholerae O139 strains. The ten non-O1/ non-O139 strains harboured the virulence genes $c t x A$, zot, ace, RS1, hlyA, ompU, rtxA and sxt. One of the El Tor strains (PL-68) was negative for $t c p A$, possibly because of a polymorphism that could not be detected by primers specific for El Tor and the classical type of tcpA. These results indicated that $V$. cholerae $\mathrm{O} 1, \mathrm{O} 139$ and particularly non-O1/non-O139 strains of clinical origins have the ability to cause diarrhoea. Indeed, it is clear that the latter group are able to precipitate a cholera-like syndrome with the capacity to cause a localized outbreak (Sharma et al., 1998).

Some interesting and unusual findings were observed in the PCR results. Three El Tor strains lacked the V. cholerae O1-specific gene $(V c-O 1)$ and three O139 strains had both $\mathrm{Vc}-\mathrm{O} 1$ and $\mathrm{Vc}-\mathrm{O} 139$ genes. Moreover, of ten non-O1/non$\mathrm{O} 139$ strains, seven harboured $\mathrm{Vc}-\mathrm{O} 1$ genes. These results suggested that $V$. cholerae $\mathrm{O} 139$ may have originated from an $\mathrm{O} 1$ ancestry through the lineage of non-O1/non-O139. It is noteworthy that four serogroups were identified and reported previously that have been derived from an $\mathrm{O} 1$ progenitor by serogroup conversion at the O-antigen $\left(w^{*} b^{\star}\right.$ region (Blokesch \& Schoolnik, 2007).

Phenotypic characterization of these $V$. cholerae strains by phage typing was also a point of interest in this study as phage typing is routinely performed in our laboratory. Phage typing results of $V$. cholerae $\mathrm{O} 1 \mathrm{El}$ Tor strains revealed that two types, T27 and T25, in particular were predominant among strains isolated from different geographical regions of India and from both Bangladesh and Brazil (Table 1). However, greater variation in the phage types was evident for tetracycline-resistant strains isolated from Kolkata than in other strains. Distribution of virulence-associated and regulatory protein genes into a single phage type was observed (Fig. 1); the $V c$-Ol gene was absent within phage type T27 in strain PL-47. Strains of phage types T25 and T24 did not show significant variation in their pathogenicity gene pattern. One (PL-68) of the seven phage-non-typable O1 El Tor strains was characterized as susceptible to trimethoprim, sulfamethoxazole and streptomycin due to the absence of the sxt gene. None of the non-O1/non-O139 strains had an intact $V$. cholerae pathogenicity island region.

Bhowmick et al. (2007) considered that strains of $V$. cholerae belonging to a single phage type originate from a single clone. This is corroborated by the present study where the distribution of virulence genes correlated strongly with phage types. Thus, regularly monitoring virulence gene patterns and genetic changes of pathogenic $V$. cholerae in conjunction with the phage typing pattern is useful for tracing the origins of newly emerging clones of this species.

\section{ACKNOWLEDGEMENTS}

We thank S. Saha for his continuous help and assistance during the course of the work.

\section{REFERENCES}

Bhanumathi, R., Sabeena, F., Isac, S. R., Shukla, B. N. \& Singh, D. V. (2003). Molecular characterization of Vibrio cholerae O139 Bengal isolated from water and the aquatic plant Eichhornia crassipes in the river Ganga, Varanasi, India. Appl Environ Microbiol 69, 2389-2394.

Bhowmick, T. S., Das, M., Roy, N. \& Sarkar, B. L. (2007). Phenotypic and molecular typing of Vibrio cholerae $\mathrm{O} 1$ and $\mathrm{O} 139$ isolates from India. J Infect 54, 475-482.

Binsztein, N., Costagliola, M. C., Pichel, M., Jurquiza, V., Ramírez, F. C., Akselman, R., Vacchino, M., Huq, A. \& Colwell, R. (2004). Viable but nonculturable Vibrio cholerae $\mathrm{O} 1$ in the aquatic environment of Argentina. Appl Environ Microbiol 70, 7481-7486.

Blokesch, M. \& Schoolnik, G. K. (2007). Serogroup conversion of Vibrio cholerae in aquatic reservoirs. PLoS Pathog 3, e81.

Chakrabarti, A. K., Ghosh, A. N. \& Sarkar, B. L. (1997). Isolation of Vibrio cholerae phages to develop a new phage typing scheme. Indian J Med Res 105, 254-257.

Chattopadhyay, D. J., Sarkar, B. L., Ansari, M. Q., Chakrabarty, B. K., Roy, M. K., Ghosh, A. N. \& Pal, S. C. (1993). New phage typing scheme for Vibrio cholerae O1 biotype El Tor strains. J Clin Microbiol 31, 1579-1585.

Chow, K. H., Ng, T. K., Yuen, K. Y. \& Yam, W. C. (2001). Detection of RTX gene in Vibrio cholerae by PCR. J Clin Microbiol 39, 2594-2597.

DiRita, V. J., Parsot, C., Jander, G. \& Mekalanos, J. J. (1991). Regulatory cascade controls virulence in Vibrio cholerae. Proc Natl Acad Sci U S A 88, 5403-5407.

Faruque, S. M., Chowdury, N., Kamruzzaman, M., Dziejman, M., Rahman, M. H., Sack, D. A., Nair, G. B. \& Mekalanos, J. J. (2004). Genetic diversity and virulence potential of environmental Vibrio cholerae population in a cholera-endemic area. Proc Natl Acad Sci U S A 101, 2123-2128.

Hall, R. H., Khambaty, F. M., Kothary, M. H., Keasler, S. P. \& Tall, B. D. (1994). Vibrio cholerae non-O1 serogroup associated with cholera gravis genetically and physiologically resembles O1 El Tor cholera strains. Infect Immun 62, 3859-3863.

Herrington, D. A., Hall, R. H., Losonsky, G., Mekalanos, J. J., Taylor, R. K. \& Levine, M. M. (1988). Toxin, toxin co-regulated pili, and the toxR regulon are essential for Vibrio cholerae pathogenesis in humans. J Exp Med 168, 1487-1492.

Huhulescu, S., Indra, A., Stoeger, A., Ruppitsch, W., Sarkar, B. L. \& Allerberger, F. (2007). Occurrence of Vibrio cholerae serogroups other than O1 and O139 in Austria. Wien Klin Wochenschr 119, 235241.

Kaper, J. B., Glenn, G., Morris, J. \& Levine, M. M. (1995). Cholera. Clin Microbiol Rev 8, 48-86.

Karaolis, D. K. R., Johnson, J. A., Bailey, C. C., Boedeker, E. C., Kaper, J. B. \& Reeves, P. R. (1998). A Vibrio cholerae pathogenicity island associated with epidemic and pandemic strains. Proc Natl Acad Sci U S A 95, 3134-3139.

Levine, M. M., Kaper, J. B., Herrington, D., Losonsky, G., Morris, J. G., Clements, M. L., Black, R. E., Tall, B. \& Hall, R. (1988). Volunteer 
studies of cholera deletion mutants of Vibrio cholerae $\mathrm{O} 1$ prepared by recombinant techniques. Infect Immun 56, 161-167.

Lin, W., Fullner, K. J., Clayton, R., Sexton, J. A., Rogers, M. B., Calia, K. E., Calderwood, S. B., Fraser, C. \& Mekalanos, J. J. (1999). Identification of a Vibrio cholerae RTX toxin gene cluster that is tightly linked to the cholera toxin prophage. Proc Natl Acad Sci U S A 96, 1071-1076.

Miller, J. F., Mekalanos, J. J. \& Falkow, S. (1989). Coordinated regulation and sensory transduction in the control of bacterial virulence. Science 243, 916-922.

Mukhopadhyay, A. K., Garg, S., Nair, G. B., Kar, S., Ghosh, R. K., Pajni, S., Ghosh, A., Shimada, T., Takeda, Y. \& Takeda, T. (1995). Biotype traits and antibiotic susceptibility of Vibrio cholerae serogroup $\mathrm{O} 1$ before, during and after the emergence of the $\mathrm{O} 139$ serogroup. Epidemiol Infect 115, 427-434.

O'Shea, Y. A., Reen, F. J., Quirke, A. M. \& Boyd, E. F. (2004). Evolutionary genetic analysis of the emergence of epidemic Vibrio cholerae isolates on the basis of comparative nucleotide sequence analysis and multilocus virulence gene profiles. J Clin Microbiol 42, 4657-4671.

Rajanna, C., Wang, J., Zhang, D., Xu, Z., Ali, A., Hou, Y. M. \& Karaolis, D. K. R. (2003). The Vibrio pathogenicity island of epidemic Vibrio cholerae forms precise extrachromosomal circular excision products. J Bacteriol 185, 6893-6901.

Ramamurthy, T., Bag, P. K., Pal, A., Bhattacharya, S. K., Bhattacharya, M. K., Shimada, T., Takeda, T., Karasawa, T.,
Kurazono, H. \& other authors (1993). Virulence patterns of Vibrio cholerae non-O1 strains isolated from hospitalized patients with acute diarrhoea in Calcutta, India. J Med Microbiol 39, 310-317.

Sarkar, B. L., De, S. P., Saha, M. R., Niyogi, S. K. \& Roy, M. K. (1994). Validity of new phage typing scheme against Vibrio cholerae O1 biotype El Tor strains. Indian J Med Res 99, 159-161.

Sharma, C., Thungapathra, M., Ghosh, A., Mukhopadhyay, A. K., Basu, A., Mitra, R., Basu, I., Bhattacharya, S. K., Shimada, T. \& other authors (1998). Molecular analysis of non-O1, non-O139 Vibrio cholerae associated with an unusual upsurge in the incidence of cholera-like disease in Calcutta, India. J Clin Microbiol 36, 756-763.

Singh, D. V., Matte, M. H., Matte, G. R., Jiang, S., Sabeena, F., Shkula, B. N., Sanyal, S. C., Huq, A. \& Colwell, R. R. (2001). Molecular analysis of Vibrio cholerae O1, O139, non-O1, and non-O139 strains: clonal relationships between clinical and environmental isolates. Appl Environ Microbiol 67, 910-921.

Singh, D. V., Isaac, S. R. \& Colwell, R. R. (2002). Development of a hexaplex PCR assay for rapid detection of virulence and regulating genes in Vibrio cholerae and Vibrio mimicus. J Clin Microbiol 40, 4321-4324.

Wachsmuth, K., Olsvik, O., Evins, G. M. \& Popovic, T. (1994). Molecular epidemiology of cholera. In Vibrio Cholerae and Cholera, pp. 357-370. Edited by I. K. Wachsmuth, P. A. Blake \& O. Olsvik. Washington, DC: American Society for Microbiology.

WHO (1993). Guidelines for Cholera Control. Geneva: World Health Organization. 